\title{
Travelling in Spirit: From Friuli to Siberia
}

\author{
Carlo Ginzburg
}

UCLA, USA and Scuola normale superiore, Pisa, Italy

I. I never met a shaman in my life. My knowledge of shamans and their European counterparts (if they ever existed: an issue I will address later) is unashamedly bookish. But should I really be ashamed? Isn't history an honorable craft, which more often than not deals with books and papers, old and new, preserved in libraries and archives?

These rhetorical questions will lead us nowhere, unless we assume that both historians and anthropologists share an experience of distance - the distance between the observers' categories and those of the actors. ${ }^{\mathrm{I}}$ I am referring to the well known distinction between etic and emic levels of analysis that Kenneth Pike, anthropologist, linguist and missionary, picked up and reworked from linguistics (etic and emic referring, respectively, to phonetics and phonemics). As I argued elsewhere, Pike's argument might be rephrased as follows: observers (including historians) ask etic questions which are either anachronistic or ethnocentric, or both, in order to retrieve, through a long and sometimes difficult trajectory, emic answers - the categories and voices of the actors. Far from identifying a scientific approach with either the etic or the emic (as Pike and Lévi-Strauss did, respectively) I have argued that historians and anthropologists should engage in a sustained dialogue between the two dimensions, etic and emic. ${ }^{2}$

2. The dichotomy between observers' and actors' categories will provide a framework for the case study I am going to share with you: a retrospective evaluation of my own research experience over thirty years, from the early sixties to the late eighties, from my first

How to cite this book chapter:

Ginzburg, C. 20I6. Travelling In Spirit: From Friuli to Siberia. In: Jackson, P. (ed.) Horizons of Shamanism: A Triangular Approach to the History and Anthropology of Ecstatic Techniques. Pp. 35-5I. Stockholm: Stockholm University Press. DOI: http://dx.doi.org/Io.I6993/bag.d. License: CC-BY 4.0 
book (I benandanti, translated into English as The Night Battles) to Storia notturna. Decifrazione del sabba, translated into English as Ecstasies. Deciphering the Witches' Sabbath. As a student back in I959, I made a triple, sudden decision: to become a historian; to work on witchcraft trials in early modern Europe; to focus on the attitudes, beliefs, voices of the women and men accused of witchcraft. The latter decision had both biographical and ideological implications: on the one hand, my memories as a Jewish child during the Second World War; on the other, my recent encounter with Antonio Gramsci's Prison Notebooks, written in the Fascist prisons. I had been particularly impressed by Gramsci's remarks on "the culture of subaltern classes" (cultura delle classi subalterne). But my project to approach witchcraft trials as a crude form of class struggle was also a deliberate updating of Jules Michelet's romantic vision of the "Witch" as a symbol of social revolt.

A document, dated I 5 I9, I found in the Inquisition files preserved in the State Archive of Modena, seemed to provide support for my initial hypothesis: a trial against a peasant, Chiara Signorini, accused of having cast a spell against her landlady, who had ejected Chiara from her own possession. But in the essay (the first I ever published) dedicated to that trial I ultimately pointed at a broader issue, i.e. the cultural clash between the inquisitor and the peasant woman. "Cases such as that of Chiara Signorini" I concluded "can have exemplary value even in their most unique aspects". ${ }^{3}$ The word for "exemplary" in the original Italian version - "paradigmatico" - did not imply an allusion to Thomas Kuhn's paradigm, since The Structure of Scientific Revolutions was published the year after: but the tension between cases and generalizations was already at the heart of my research, where it has remained ever since. I will come back to this issue later.

3. The inquisitor who conducted Chiara Signorini's trial was the Dominican friar Bartolomeo Spina, the author of a well known demonological treatise (Quaestio de strigibus). May we describe him as an observer, who relied upon psychological and physical pressures to convince Chiara to answer his own questions - his own etic questions - following his lead? If we were to accept this implicit analogy we might also note that Chiara withstood the 
Inquisitor's pressures on one matter only: she stubbornly refused to confess she had taken part in the witches' Sabbath. May we say that the latter element was not part of Chiara's emic categories?

A long time ago I began to work in this direction in an essay entitled "The Inquisitor as Anthropologist". ${ }^{4}$ A reversal of the analogy - "The Anthropologist as Inquisitor" - would stress the concern for truth, as well as the cultural distance, shared by both anthropologists and inquisitors vis-à-vis the actors they were confronted with (i.e. natives, defendants). But as soon as we look at those asymmetrical relationships from a distance, everything becomes more complex: both observers and actors would turn into actors. For instance, the observer I was at that time would become, in the eyes of the observer I am now, an actor. Let me add immediately that I am not particularly attracted by the fashionable notion of agency. Acting, or acted upon? I am tempted to answer this question in Latin, echoing (with due qualifications) Martin Luther's famous dictum: actus, non agens. As you will see, the multiplication of egos I will deal with in my presentation does not have a narcissistic purpose - quite the contrary.

4. The unexpected feeling of disappointment I experienced in discovering a document which seemed to confirm my initial hypothesis - witchcraft as a crude form of class struggle - had left me without a specific research program. I spent one year (1963) wandering across Central and Northern Italy, searching for fragments of Inquisition archives and reading as many witchcraft trials as I could, at random. One day, while I was consulting the Inquisition trials preserved in State Archive of Venice, I came across a testimony given in I 59 I by Menichino, a young cowherd from Latisana, a little town in Friuli. He said that, since he was born in a caul (that is, wrapped in the amniotic sac) he was a benandante (literally, somebody who goes for the good): therefore, he was compelled to dream, three times a year, to go "like in a smoke" in the field of Josaphat, where he fought with fennel stalks against the witches, "to preserve the faith". Then he added: "when the benandanti won it was a sign of a good harvest". The dream (Menichino explained) first came to him after a conversation he had had with a friend, Giambattista Tamburlino, who had also declared he was a benandante. "When you have to come, you 
will come" Tamburlino said. "You will not be able to force me" Menichino replied. His friend insisted: "You will have to come anyway". "And a year after these conversations", Menichino went on "I dreamed that I was in Josaphat's field".

In an essay I wrote many years ago I tried to reflect on the reasons for my own excitement in coming across that document - a discovery that led me to write a book on $\mathrm{I} 6^{\text {th }}$ - and $\mathrm{I} 7^{\text {th }}$-century Friulian benandanti. ${ }^{6}$ I was astonished at the amount of unexpected details which emerged from those documents, unveiling a deep layer of peasant beliefs. As I told in my book, the Inquisitors tried to fill the gap between what they expected and what they heard from the benandanti, urging the benandanti to confess that they were not counter-witches at all but real witches. But in my retrospective reflection I refrained from explaining (first of all, to myself) why an analogy between Friulian benandanti and Siberian shamans had struck me as being self-evident almost right away. I will address this issue now.

5. In Andrei Znamenski's helpful book on the impact of shamanism on the Western imagination, I have been enlisted among the scholars who felt the impact of Mircea Eliade's "cross-cultural and transcendental vision of shamanism". ${ }^{7}$ "In fact", Znamenski remarked, "in his essay Some Observations on European Witchcraft (I975) Eliade had already pointed to the similarities he had noticed between witches' practices described in European folklore and shamanic trances". ${ }^{8}$ In fact, in that essay, as any reader (Znamenski excepted) can see, Eliade started from my own book (published in I966) to advance parallels between Friulian benandanti and Romanian calusarii, as evidence of his earlier argument about shamanism as a broad, cross-cultural phenomenon. ${ }^{9}$ I will leave aside my strong reservations about Eliade as a scholar, which I have expressed elsewhere. ${ }^{\circ}$ Here I would like to point out that when I first came across the benandanti I had not read Eliade's writings on shamanism. What I knew about shamanism came from another, far more original source: Ernesto de Martino's Il mondo magico, published in I948, later translated into seven languages. ${ }^{\text {II }}$

The impact of de Martino's book on the English-speaking world has, so far, been minimal. ${ }^{\mathrm{I2}}$ This may be partly ascribed to a 
scandalously inadequate translation, first published in I972, after the author's death, and then reprinted several times, with the title Primitive Magic: the Psychic Powers of Shamans and Sorcerers. ${ }^{13}$ In this English version the introduction, as well several passages and footnotes, were tacitly suppressed; some quotations were tacitly added; above all, de Martino's highly nuanced, peculiar style was grossly simplified, to the point of distortion.

I will say something about de Martino's complex work and personality in a while. But first, let me point out that shamans play a crucial role in Il mondo magico, as its very beginning - a two-page long quotation from Sergei Shirokogoroff's The Psychomental Complex of the Tungus, published in London in 1935, a book which, as you know, has remained a classic reference on shamanism until today. ${ }^{\mathrm{I}}$ Let me take a short passage from that quotation:

"In the state of great concentration the shamans and other people may come into communication with other shamans and ordinary people. (...) The shamans use this method in their common practice when they want to meet some people or other shamans. Sometimes they do not realize the motive as to why they leave one place or go to another where they meet the person who called them - 'they go because they feel they must go'." I5

This passage must have crossed my mind as soon as I read the dialogue between Tamburlino and Menichino, the two benandanti from Latisana: "When you have to come, you will come". Their conversation worked as an initiation, anticipating - and apparently producing - the specific content of the dream Menichino had one year later. (Later, I found detailed descriptions of initiations and dreams in dozens of trials against Friulian benandanti). If at that time I had had direct access to Shirokogoroff's book, I would have found more parallels. For instance, the following passage, which de Martino skipped in his quotation from the aforementioned text:

“...before falling asleep the Tungus express their desire to see distant places and people. If the dream occurs the fact is interpreted as a voluntary direction of the soul" ${ }^{16}$

6. In the nineteen sixties my knowledge of Shirokogoroff's ethnographic work was still mediated, and filtered, by de Martino. 
I mention this seemingly irrelevant detail in my attempt to reconstruct a chapter in the historiography of shamanism, conceived as a case study in the transmission of knowledge. An experiment in intellectual history, perhaps? Yes, but even more an experiment in the history of reading - an activity shared today by a large part of the human kind, but still inadequately analyzed in its complexity.

The relatively simple case I am dealing with implies a chain of transmission based on three links: (a) Shirokogoroff's Psychomental Complex of the Tungus; (b) de Martino's reading of that book (which he first reviewed, and then quoted extensively in Il mondo magico); (c) my indirect and partial access to Shirokogoroff's book through de Martino's Il mondo magico. In principle, in order to understand how the chain worked one should focus on each of its links. The limits of my knowledge (first of all, linguistic) prevent me from dealing adequately with Shirokogoroff's truly impressive work, which I have only recently read. But something should be said about its theoretical framework, and especially its anti-ethnocentric attitude, duly pointed out by Andrei Znamenski in his detailed comment. ${ }^{17}$ But "anti-ethnocentric attitude" is a mild label for Shirokogoroff's radical relativism. His sarcastic references to "European folklore" included medieval cosmogonies, $\mathrm{I} 9^{\text {th }}$-century evolution theory, and ultimately "science" (in telling quotation marks), as in the following passage:

"...cosmogony of the Middle Ages is already fixed as medieval folklore, regardless of whether it was created by the most learned scholastic scholars or by the ignorant farmers. We may say that the theory of evolution with its teleological background as it was practiced, professed, in the European universities in the middle of the $19^{\text {th }}$-century, in the eyes of the present generation being styled as a 'scientific theory', in the eyes of later generations will appear in its real form of European folklore of a given period. (...) The basis of this attitude is a strong belief in the difference between 'science' as knowledge of realities and method, on the one hand, and 'folk imagination' crystallized in 'folklore' (in the common sense)." I8

Shirokogoroff's dismissive remark on the theory of evolution and its teleological background had a self-critical implication. A few 
years before he had put forward a theory of ethnos according to which:

"The division of mankind into the ethnical units (ethnoses) is a natural function which is at the same time an impulse of development of man as a whole" and culture "is a product of a purely biological function, and all phenomena of a physical, social, psychic and technical order are concrete manifestations of this process". ${ }^{19}$

In The Psychomental Complex of the Tungus ethnical units still play a central role, although Shirokogoroff explicitly rejected traditional racist theories as:

"confined only to phenotypic rough characters, such as forms of the head, body, limbs and hair, also pigmentation, while perhaps the most important characters, the chemical functional complex and physical constructive complex remain beyond observation, without speaking of the chromosomes and plasma, about the differences of which in human species we have only vague guesses". ${ }^{20}$

Shirokogoroff could not foresee that in a few decades Luigi Cavalli Sforza and other geneticists would have demonstrated that within the human species there are no significant genetic differences. But Shirokogoroff's commitment to scientific progress (like in the aforementioned passage) apparently implied a distantiation from his early positivist background. In a footnote (Shirokogoroff often used them for methodological digressions) he commented on the "ambiguous term 'objective", remarking that a "philosophical" discussion" about it:

"nowadays would be quite superfluous for no abstraction of the thinking process is possible, the process being physically bound with the cognizing individual and all his cognition is a mere reaction of the milieu. (...) When I oppose 'objective' to 'subjective' I have in view only a relative elimination of rude feelings and now quite evident theoretical aberrations which are still prevailing in the young sciences". ${ }^{2 \mathrm{I}}$

Shirokogoroff's radically emic approach (to use Kenneth Pike's categories once again) must be interpreted in the light of those passages. His painstaking ethnographic accounts of shaman practices were fuelled by a scornful reversal of traditional eth- 
nographic assumptions. "Folklore" was science, and science was "European folklore". Nowadays, the shocking overtone of the following remark could easily be missed:

"In so far as the shaman uses his intuition in the 'finding of causes' he does not differ from any other man who is using the method of breaking of the existing ethnographic complex as a means for proceeding from the known to the unknown". ${ }^{22}$

In a previous passage Shirokogoroff had written "The Tungus have many "facts" supporting their hypothesis" about ojan, i.e. spirits. ${ }^{23}$

In reading a statement like this I am tempted to compare The Psychomental Complex of the Tungus with another book also published in 1935, in Basel: Ludwik Fleck's Entstehung und Entwicklung einer wissenschaftlichen Tatsache (Genesis and Development of a Scientific Fact), made posthumously famous by Thomas Kuhn in his Structure of Scientific Revolutions. For the time being, I am unable to say whether Fleck's and Shirokogoroff's radical relativism could be regarded as similar developments from a common source.

But coming back to Shirokogoroff: is a purely emic approach possible? The answer is no. Shirokogoroff himself once wrote: "As a matter of fact, we have only one method which may be used, namely, the comparative method" - a sentence which might have inspired Evans-Pritchard's famous gloss "and that is impossible". ${ }^{24}$ Comparison necessarily implies an etic point of view, which for Shirokogroff coincided with his theory of ethnos probably the most problematic element of his work. Although he changed his view about them, he took ethnic units for granted.

7. De Martino owned a copy of The Psychomental Complex of the Tungus, published a review of it in 1942 , but was already extensively quoting it in 1940. ${ }^{25}$ What brought Shirokogoroff's book to his attention was, presumably, another book mentioned in $I l$ mondo magico: Wilhelm Mühlmann's Methodik der Völkerkunde, Stuttgart I938. ${ }^{26}$

Mühlmann, the author of a well known history of anthropology went through a long and successful academic career in anthropology and folklore; two bibliographies dedicated to him after the War duly included his earlier books on Rassenkunde (he was 
a full-fledged Nazi). ${ }^{27}$ In his Methodik - in many ways a remarkable book - he repeatedly mentioned, and warmly praised, The Psychomental Complex as an example of accomplished functionalist anthropology, based on a historical and psychological approach. Moreover, Mühlmann advanced some challenging comparisons between Shirokogoroff's Psychomental Complex and another book, recently published: Gregory Bateson's Naven..$^{28}$ In an obituary, published in I940, Mühlmann included long passages from letters sent by Shirokogoroff (who died the year before) from his exile in China in the late ' 3 os: violent anti-British tirades, cautious appreciation of the political developments in Germany, insightful self-reflections on The Psychomental Complex of the Tungus. ${ }^{29}$

De Martino may have come across that obituary: but his interest in Shirokogoroff's work was located elsewhere. In a long article, the first part of which came out in 1942 (it later became, in revised form, the first chapter of Il mondo magico) de Martino objected to the customary skepticism, shared by almost all ethnologists, concerning the reality of magical powers among "primitive" populations. This scandalous issue should be seriously addressed, de Martino argued, on the basis of parapsychology and related phenomena, which he had been deeply interested in since his youth. ${ }^{30}$ In this perspective, de Martino quoted long passages from The Psychomental Complex as evidence for the reality of magical powers among the Tungus. The "facts" that Shirokogoroff had recorded in detail, driven by the cognitive imperatives of his radical relativism, were inscribed by de Martino in his own, very different, perspective. Let me say right away that I do not share (and I never did) either de Martino's interest in parapsychology or his attempt to demonstrate the reality of magical powers. But I was (and I am) deeply interested in the bold theoretical argument which de Martino advanced in $\mathrm{Il}$ mondo magico. Here is a highly compressed, and necessarily inadequate, presentation of it.

Today we are used to taking reality for granted, along with our presence in it: but this, de Martino argued, is the outcome of a long historical process, in which magic played a crucial role. As one learns from accounts based on ethnographic fieldwork on 
different cultures, human beings, when confronted with highly critical situations, are threatened by a "loss of presence" - the risk of being submerged in the world. (Once again, de Martino was relying upon Shirokogoroff's work on the Tungus, especially on what he called "olonism" - a compulsive mimicry of other people's behavior). In those critical situations the shaman acts as a cultural hero, reestablishing the human presence in the world. The shaman's performance is a relic from an unrecorded past. Il mondo magico is a bold attempt to retrieve this past - a layer which took place before history, making human history possible. ${ }^{31}$

Needless to say, de Martino's argument is entirely speculative..$^{32}$ But until recently I was not aware of the deep emotional overtones of de Martino's reading of The Psychomental Complex of the Tungus. They emerge in Giordana Charuty's fine biography of de Martino, based on a large number of unpublished documents: Les vies antérieures d'un anthropologue (The Former Lives of an Anthropologist). In his youth de Martino had suffered from epileptic seizures, which he reinterpreted, retrospectively, in the framework of his own concept of "loss of presence":

"The experience of epileptic 'aura' is the sign that presence is going to weaken... [After the crisis] presence re-emerges from the shipwreck, along with a world which has retrieved its forms, its feelings. It was like sliding down from history, slowly". ${ }^{33}$

In de Martino's Il mondo magico we can easily detect - today a strong element of conscious personal identification with the shaman and his world. Shirokogoroff's approach appealed to de Martino not only for its intrinsic intellectual value, but also for its rejection of earlier pathological interpretations based on "arctic hysteria". By turning European science into European folklore, and the shaman into a cultural hero, Shirokogoroff paved the way for de Martino's interpretation.

8. Il mondo magico gave me an indirect access to Shirokogoroff's work on Tungus shamans, as well as a powerful interpretive tool: de Martino's "loss of presence". Both elements affected my response to the testimony of Menichino da Latisana, which I stumbled upon in the Venice State Archive. I discovered more Inquisition trials, in which male and female benandanti talked 
at length about the battles they used to fight in spirit, usually four times a year, against witches, for the fertility of the crops. Later, in the introduction to my book, I wrote: "I have not dealt with the question of the relationship which undoubtedly does exist between benandanti and shamans" (in the Italian version I had written, even more bluntly, "esistente", existing). ${ }^{34}$ A stab in the dark, which many years afterwards I decided to turn into a research project.

Its outcome- Storia notturna, translated into English as Ecstasies: Deciphering the Witches' Sabbath - has been hotly debated. ${ }^{35}$ I will not attempt to retrace the trajectory which led me to argue that the image of the witches' Sabbath emerged from the convergence between an aggressive conspiratorial stereotype and a deep layer of shamanistic beliefs. I will limit myself to making some comments on the most debatable element of my book: the attempt to rely on a dual approach, morphological and historical.

What ultimately led me to morphology was my distrust visa-vis shamanism as a transcultural category. If I had accepted it, the analogy between the Friulian benandanti and Siberian shamans, which came to my mind at the very beginning of my research, would have found an immediate, and seemingly legitimate, explanation. My attitude was different: the analogy, I thought, implied a connection which I felt unable to address. From an historian's point of view, the question I was confronted with was inadmissible.

I wandered for a couple of years, reading extensively, without a definite plan, reading works of different kinds on witches and shamans. Then chance once again befell my path. While I was visiting the Archaeological Museum in Siracusa, I was suddenly struck by a detail of a huge Greek vase representing a battle of the Amazons, which reminded me of a similar detail in a fresco by Piero della Francesca in Arezzo. I decided to commit myself to a completely new project: research on Piero, which ultimately became a book dealing with some of his works. ${ }^{36}$ Many years later I realized that such detour into art history unconsciously addressed the problem I was grappling with in my research on the witches' Sabbath: the relationship between form and context.

Piero della Francesca's pictorial trajectory is a much debated topic among art historians, due to lack of chronological evidence. 
I tried to circumvent the obstacle by focusing on contextual elements (iconography and patrons) which suggested a chronology that significantly diverged from the one advanced by art historians, based on stylistic data. To address the analogy between benandanti and shamans I made a similar experiment, but in reverse: I used a morphological approach which led me to put forward a plausible historical context. As I explained in my book Storia notturna, I was especially inspired by two imaginative developments of Goethe's morphology: Vladimir Propp's work on folktales and Ludwig Wittgenstein's reflections on "family resemblances".

9. My work on witchcraft has been harshly criticized, among others, by Willem de Blécourt, who has written a few essays on it. Let me quote a passage from one of them, concerning Storia notturna:

"These far-reaching conclusions are based on an analysis that is vaguely structural, profoundly phenomenological, only morphological in name and hardly historical; it is selective instead of serial and devoid of contexts. (...) How can one put history back into a linking exercise based on superficial resemblances?" 37

Each of these strictures - "selective instead of serial", "devoid of contexts", "superficial resemblances" - deserves a specific discussion. Let me start from the latter, which goes back to morphology. I will briefly mention two pieces of evidence which convinced me that the Friulian benandanti were not an isolated phenomenon. The first is a trial which took place in Livonia at the end of $\mathrm{I} 7^{\text {th }}$-century. The defendant, an old man named Thiess, confessed he was a werewolf. Three times a year he would go with other werewolves, in the form of wolves, "beyond the sea", in hell, to fight the witches for the fertility of the harvests. We, the werewolves (Thiess said), are "the hounds of God", and our souls ascend to God. Likewise, many benandanti said that, metamorphosed into animals, they fought the witches for the faith and the fertility of the crops. ${ }^{3^{8}}$ The second piece of evidence - Freud's famous case study on the "wolf-man" - provided me with a further link between benandanti and werewolves: according to Slavic folk beliefs, people born in a caul (i.e. wrapped in the amniotic sac) were supposed to become werewolves. The "wolf-man”, Freud's patient from Russia, was born in a caul: a detail that Freud 
recorded, without realizing its meaning in folk culture. The dream which marked forever the little Russian child - wolves sitting in the branches of a tree and gazing at him - should be regarded, I argued, as a sort of initiation, shaped by the folktales he must have heard from his nianja. "The wolf-man's fate" I remarked "differed from what it might have been two or three centuries earlier. Instead of turning into a werewolf he became a neurotic, on the brink of psychosis". ${ }^{39}$ A conclusion that Shirokogoroff (I realize now) would have immediately subscribed to.

It would seem hard to dismiss the convergences I mentioned as "superficial". None of the traits involved - and even less their combination - are obvious. But they are certainly related to anomalous, not to say unique cases. According to de Blécourt, Storia notturna "harbours a dimly concealed north Italian and even Friulian bias". The reason for the alleged "Friulian bias" are given by de Blécourt himself a few paragraphs later, in a comment to my first book, I benandanti: "[it] contains an elegant and well considered presentation of surprising material which is still unique in a European witchcraft context". $4^{\circ}$ Unique it was. Retrospectively, I realize that I started from a chance event, an anomalous document (Menichino's confession found in the State Archive of Venice) turning it into a case, first Friulian, then Eurasian. (Incidentally, both terms - case, chance - share the same Latin etymology: cadere, to fall).

Here comes de Blécourt's second criticism of my approach, which he labelled "selective instead of serial". But I will not waste your time in rejecting the naive idea that only a serial approach would be appropriate to human sciences and humanities. ${ }^{4 \mathrm{I}} \mathrm{I}$ used clues - selective clues - in order to build up an experiment which was, as experiments always are, based on a selection of data. Contextual evidence was not part of the experiment. Hopefully, some further research will use it to confirm, to rework or to refute my argument concerning the long term continuities across the Eurasian continent.

According to de Blécourt "the concept of continuity not only provided the framework for the contextualized details which plague Storia notturna; it is also one of the foremost articulations of nationalist proclivities". ${ }^{42}$ I wonder whether this remark insinuates 
that I am either an Italian or a Friulian nationalist. "Ginzburg” de Blécourt wrote "never seems to have discovered the fascist leanings of the Romanian historian of religions Mircea Eliade, whom he quotes favorably in Storia [notturna]". ${ }^{43}$ In the footnote related to this remark no references to my book are mentioned. Apparently de Blécourt missed a footnote in which I had written: "The pathos of defeat inspired Eliade, who had behind him a Fascist and anti-Semitic experience (...) to construct a theory of the flight from history" [in his book The Myth of the Eternal Return]. ${ }^{44}$

IO. I will not insist on the aforementioned allegations, which I regard as personally offensive (and false). But they touch upon a very important issue - the political overtones of the debate on shamans and shamanism - which de Blécourt addresses in simplistic terms. The involvement of scholars with a more or less explicit Fascist and Nazi orientation is well known. Their political and ideological commitment usually affected their research - both their approach and their results. But we must bear in mind that (as I once wrote about Georges Dumézil's work) a sharp distinction should be drawn between questions and answers. Answers that we regard as morally or politically unacceptable should not necessarily imply a dismissal of the questions they allegedly addressed. "Even racism, to take one extreme example" I argued "is one answer (scientifically unfounded and with a monstrous practical outcome) to a very real question related to the connection between biology and culture". ${ }^{45}$ The topics we are discussing, and the scholarship related to them, are full of treacherous, disturbing implications. Political correctness will not protect us.

I I. When I first read Il mondo magico I was unaware of Shirokogoroff's political orientation; I was unaware of de Martino's personal involvement in relying upon Shirokogoroff's argument; I was aware of de Martino's attempt to demonstrate the reality of magical powers - but I didn't share it. The mixture of conscious and unconscious elements, biases and chance, I have been trying to describe, is not the exception but the rule. All our decisions are taken in a context which is more or less similar to the one I am describing. We are all acted upon and are acting at the same time. Reading can be regarded as a miniature model of all kinds of social and cultural processes - including the intricate 
transmission, based on tales, rituals, and dreams, which I have tried to explore flying in spirit from Friuli to Siberia.

\section{Notes}

I. For a more obvious approach see Znamenski 2007:I87: “indeed, as student of shamanism, Eliade was a perfect example of an armchair scholar - extremely well read in secondary sources, he never observed a single shaman". On Eliade's work, see later.

2. Pike I967; I990; Ginzburg 201 2 b.

3. Ginzburg [196г] 20I3a:I4.

4. Ginzburg [1988b] 20I3e (at that time I was still unaware of Kenneth Pike's dichotomy).

5. Ginzburg I983:74-77; I972:I I-I I 6.

6. Ginzburg I993:75-85; 20I 2b:21 5-227.

7. Znamenski 2007:I84-I87. See Eliade I946; I95 I.

8. Znamenski 2007:I 84-I 85 .

9. Eliade 1975.

Iо. Ginzburg 20 Iо.

II. de Martino I948. The manuscript was sent to the publisher, Giulio Einaudi, on August 8, I946: see Angelini 2007. Translations: English, French, Spanish, Czech, Hungarian, Polish, Japanese.

I2. See Ferrari 2012.

I3. The blurb refers to de Martino as if had he still been alive (he died in 1964). The first edition, published by Bay Books, Australia, was reprinted by Prism Press in 1988, I990, I999. According to a reprint with no date, entitled The World of Magic, the English translation was translated from the French version (Le monde magique, 1967).

I4. Shirokogoroff 1999.

I 5. de Martino I999:4 (quoting Shirokogoroff I935:I I fff.) (see de Martino I948:22-23) I have reinstated the quotation marks in the last sentence.

I6. de Martino I 999:5 (quoting Shirokogoroff I 935: I I fff.) The passage is omitted (...) in de Martino 1948:23. 
I7. Znamenski 2007:107-II3.

I 8. Shirokogoroff I935:42.

I9. Shirokogoroff I 924 (this is a revised translation of a paper published in Russian in 1923).

20. Shirokogoroff I935:23-24.

2I. Shirokogoroff I93 5: I I note **.

22. Shirokogoroff I935:360.

23. Shirokogoroff I935:I4I.

24. Shirokogoroff I935:4I3.

25. Archivio De Martino, 3.8.26 (Charuty 2009:259 note 65; de Martino I942a. See also de Martino I942b; de Martino I943-I946:5: "I principali risultati ottenuti finora (I940)". In I942, when he received from Father M. Schulien the suggestion to read Shirokogoroff's book, de Martino was already familiar with it (a point missed by Angelini 2008:33-34). Angelini emphasizes (pp. 33-38) the impact of Shirokorogoff's book on de Martino, relying upon the latter's remarks.

26. See de Martino I948:93 note 2 (misquoted as: Methode), roo note I. In his first book de Martino had praised Mühlmann's contribution to the Lehrbuch der Völkerkunde I937 as "speculativamente tra i più elevati che ci sia accaduto di leggere nello spoglio che abbiamo fatto della materia": de Martino I94I:I97-I98 (Mühlmann I936, is mentioned on p I92 n. 38; see also pp. I93-I95). A copy of a later book by Mühlmann I964, is preserved in de Martino's library (now at the Mediateca dell'Accademia di Santa Cecilia, Roma) with a handwritten dedication: "Dem verherten Kollegen Prof. De Martino zur freundlichen Erinnerung, Roma, 24. April I965”. De Martino died a few days later (May 6).

27. Mühlmann I936 (Il mondo, pp. 94 note I, I 59 note I). See Reimann \& Kiefer (eds.) I964; I984; Mühlmann I968. See Michel I99I; Klingemann 2009:363-373.

28. Mühlmann I938:I58, I62-I63 and passim. The preface is dated "Hamburg, I3. März I938. Am Tage der Rückkehr Oesterreichs ins Reich".

29. Mühlmann I940. 
30. See Charuty 2009:254 ff.; Satta 2005.

$3 \mathrm{I}$. In a conversation which took place in the early '60s in Rome, Angelo Brelich, the historian of religions, remarked that de Martino had tried to grasp "una frangia di ultrastoria". On the intellectual trajectory leading to Il mondo magico see my essay Ginzburg I988a.

32. For a comparison with Adorno and Horkheimer's Dialectics of the Enlightenment see Ginzburg I979b.

33. Charuty 2009:57-59 (quoting passages, translated into French, from de Martino's unpublished notes). A retrospective, not so veiled allusion to this trajectory can be found in de Martino's following remark : "il primitivo, il barbarico, il selvaggio non erano intorno a me, perché accadeva talora che anche dentro di me sentissi con angoscia risuonare arcaiche voci, e fermentare inclinazioni e suggestioni a comportamenti gratuiti, irrazionali, inquietanti: qualche cosa di caotico e di torbido, che reclamava ordine e luce. Si maturò così un corso di pensieri e di ricerche che mise capo alla tesi fondamentale del Mondo magico etc.” (de Martino I953).

34. Ginzburg 1983:XXI (I benandanti, p. XIII).

35. Cfr. Klaniczay 2010:203-204.

36. Ginzburg I98 I; I985b (with an introduction by Peter Burke).

37. de Blécourt 2007a:I28-I29. See also de Blécourt 2007b; 2007 c.

38. Ginzburg I983:28-3 I.

39. Ginzburg [1985a] 20I3d:I34.

40. de Blécourt 2007a:I28-I 29.

4I. Ginzburg [I979a] 2013b.

42. de Blécourt 2007:139.

43. de Blécourt 2007:I39.

44. Ginzburg I990:203 note 70.

45. Ginzburg 20I3f:I I4. 